Jadwiga WIERZBICKA, Danuta ŁANGOWSKA

Parasitology

\title{
PARASITIC FAUNA OF SPINY DOGFISH SQUALUS ACANTHIAS L.* OFF NEW ZEALAND
}

PARAZYTOFAUNA KOLENIA - SQUALUS ACANTHIAS L. Z OBSZARU NOWEJ ZELANDII

Institute of Ichthyology,
Academy of Agriculture,

Szczecin

A total of 55 individuals of Squalus acanthias were subject to detailed parasitologic examination. Eight parasite species belonging to the Monogenea, Cestoda, Trematoda, Nematoda, and Copepoda were found. The extent of infestation and location of parasites are described. The results are compared with literature data on spiny dogfish infestation in other areas.

\section{INTRODUCTION}

The available literature contains scarce data on parasitic fauna of Squalus acanthias caught off New Zealand. The list of parasites of the area reported, based on literature

* The fish individuala examined showed, according to the literature available to us, characteristics typical of Squalus acanthias. The only reservation was at first whether the species could have occurred so far south. A subsequent literature search (Bigelow and Schroeder, 1948; Fishes of the Western North Atlantic) did not dispel our doubts; however, Love and Moser (1983) in their work "A Checklist of Parasites of California, Oregon, and Washington Marine and Estuarine Fishes" refer to S.acanthias as occurring also off New Zealand. Therefore we have decided to bring forth our data in their present form. 
data, by Hewitt and Hine (1972) records in the spiny dogfish 7 parasitic species belonging to 5 higher taxa (Monogenea, Cestoda, Digenea, Nematoda, and Copepoda). One of those species is Calicotyle ramsayi n.sp. (Monogenea) described by Robinson (1961) as a cloaca parasite in Squalus lebruni. A digenean, Probolitrema philippi, was found by Manter (1954) in the body cavity of S. kirki, the two fish species being regarded as S.acanthias by Hewitt and Hine (1972).

The North Atlantic spiny dogfish parasites have been better documented. The relevant papers usually discuss specific groups or individual species of parasites. The general description of parasitic fauna of this host in the North Sea is given by Orłowska (1979). She examined 45 fish individuals and found 13 parasitic species belonging to 6 higher taxa. The parasitic crustaceans were worked out in detail by Kabata (1979). He lists such common parasites of the spiny dogfish as, for instance, Eudactylina acanthii and Pseudocharopinus bicaudatus. E.acanthii was recorded also off Tunesia (Raibaut et - $1 .$, 1971) and in the Mediterranean (Essafi and Raibaut, 1977. The copepod P.bicaudatus was recorded in S.acanthias by Delamare Deboutteville and Nunes (1952) and Ho (1977). The monogenean Erpocytyle squali dwelling on the spiny dogfish gills was recorded by, i.a., Pogorelceva (1964 a) in the Black Sea.

Of the endoparasites, the cestodes Tetrarhynchidea were described by Dollfus (1942). According to that author, spiny dogfish is one of the hosts of larval Hepatoxylon trichiuri and H.megacephalum and for adult Gilquinia squali. Internal parasites of the spiny dogfish in the Sea of Japan and Okhotsk Sea are listed by Žukov (1960) who examined 11 fish individuals and found 1 digenean, 3 cestode species, and nematodes Anisakis $s p$. Some papers report parasitic protozoans occurring in the host in question (Pogorelceva, 1964b; Sulman, 1966).

The present work was aimed at gaining a better knowledge on the spiny dogfish parasites off New Zealand. The results obtained make it possible to compare the parasitic fauna of that fish with the relevant literature data concerning other areas.

\section{MATERIALS AND METHODS}

The materials were collected in the New Zealand fishing grounds on 22 Feb. 1978 by Dr. Wiesław Slósarczyk during the Third Polish Antarctic Expedition on board RV „Profesor Bogucki““. The samples were collected of the Snares Islands (Ślósarczyk, 1979). The fish were brought to the laboratory frozen. A total of 55 individuals measuring $53-73 \mathrm{~cm} / 62-88 \mathrm{~cm}$ (body length, 1.c./total length, 1.t.) and weighing 960-3100 g, were examined.

The thawed fish were subject to a full parasitologic examination, the skin, eyes, nostrils, spiracles, gills, mouth cavity, stomach, intestine, liver, gall bladder, gonads, and muscles being carefully scrutinised. The nematodes and crustaceans found were fixed in 4\% formalin with physiological salt solution. The flatworms were slightly flattened on slides and fixed in $75 \%$ ethyl alcohol, alum carmine stained, dehydrated in alcohol, 
immersed in xylene, and mounted permanently in Canada balsam. Nematodes were identified in glycerin mounts.

\section{RESULTS}

The 55 spiny dogfish individuals examined were found to contain a total of 8 parasitic species belonging to the Monogenea, Cestoda, Trematoda, Nematoda, and Copepoda.

\section{MONOGENEA}

Erpocotyle squali (MacCallum, 1931) Price, 1942

The species occurred very frequently on gills. The parasites were found in as many as 53 fishes, with the invasion intensity of 1-37 parasites in a fish. The invasion incidence reached $96 \%$. The mean population invasion incidence was high, too, amounting to 8.24 parasites in a fish.

\section{CESTODA}

Hepatoxylon megacephalum (Rudolphi, 1819)

The larvae were found in 4 fishes, one in each, the parasites being located in the body cavity. The invasion incidence was $7.2 \%$; the mean population invasion incidence was very low (0.07 in a fish).

\section{TREMATODA}

\section{Probolitrema sp.}

The trematodes occurred sporadically, only 2 specimens were found in 2 fishes. The invasion incidence was $3.6 \%$. The parasites, adult forms filled with eggs, were found in the stomach. The parasites were $16.1 \mathrm{~mm}$ long, $10 \mathrm{~mm}$ wide; the mouth and ventral suckers measured 1.220 and $1.647 \times 1.568 \mathrm{~mm}$, respectively. The pharynx measured $0.647 \times 0.488 \mathrm{~mm}$. The egg dimensions were $0.058-0.063 \times 0.046-0.052 \mathrm{~mm}$. The specimens found were damaged; the shape of the ovary, located above the distorted seminal vesicle, was changed (Figs. 1 and 2). As these organs are key characters in taxonomy of the genus, it was impossible to identify the species. 


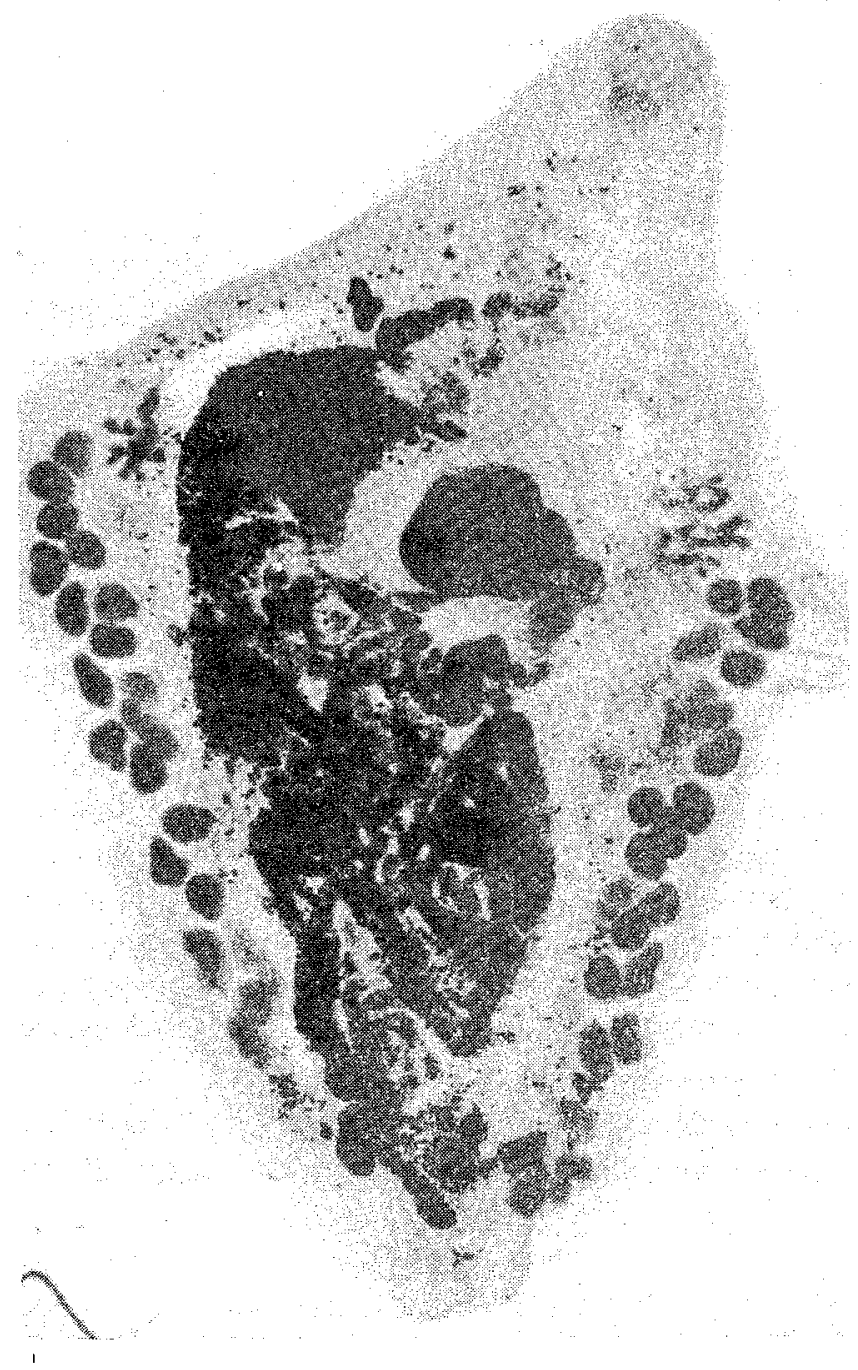

Fig. 1. Probolitrema sp. from Squalus acanthias L. stomach

\section{NEMATODA}

Anisakis simplex (Rudolphi, 1809)

The parasites were relatively rare. The invasion incidence was $12.7 \%$, up to 4 specimens being found in a fish and the mean population invasion intensity amounting to 0.25 . The nematodes found were stage 3 larvae. They occurred in cysts located on the external stomach wall. 


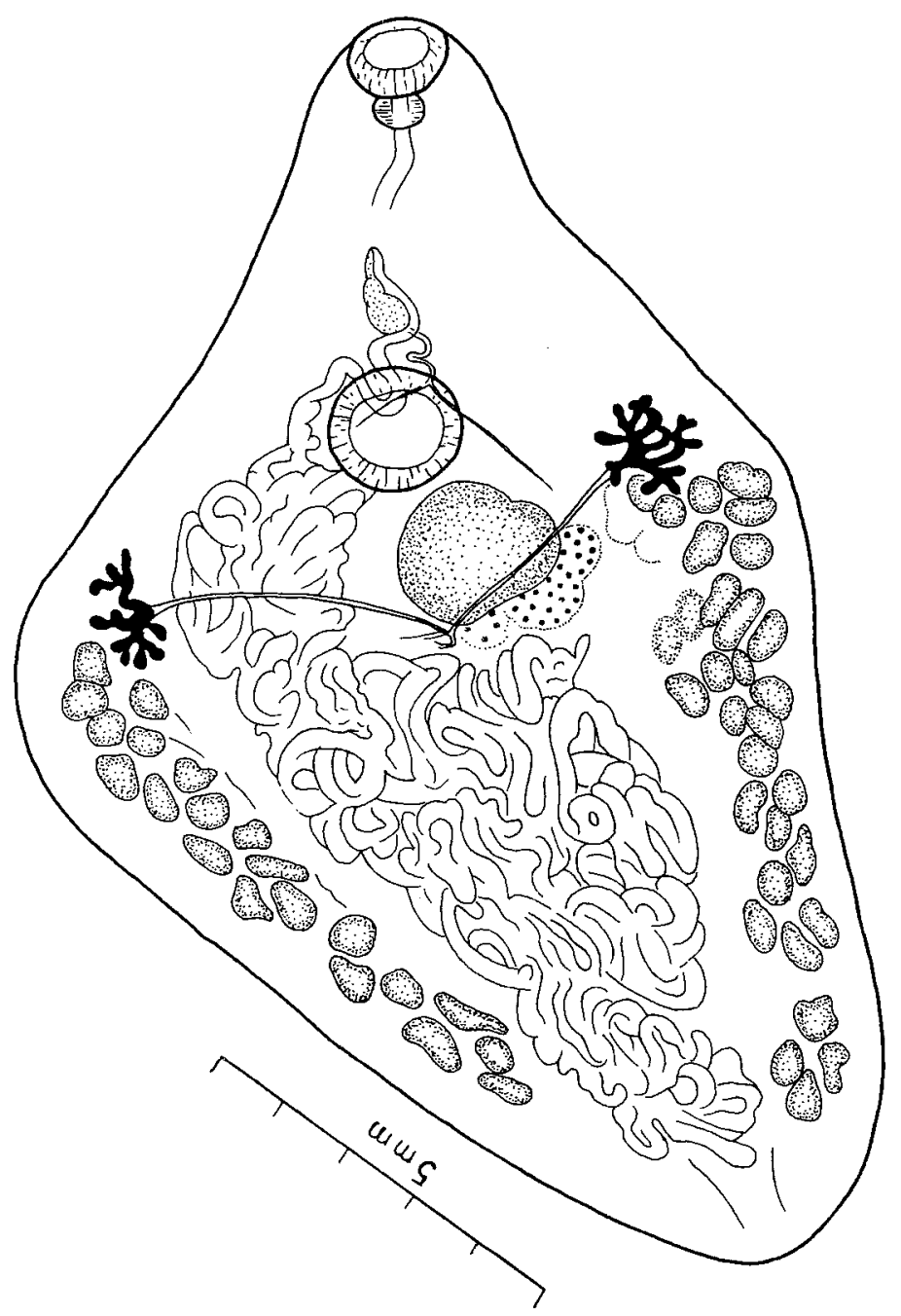

Fig. 2. Probolitrema sp. (ventral side)

Thynnascaris adunca (Rudolphi, 1802)

The extent of infestation was similar to that of Anisakis simplex. The invasion incidence was $10.9 \%$. The invasion intensity ranged from 1 to 6 parasites in a fish, with the mean population invasion intensity reaching 0.29 . A total of 16 nematodes were found. All of them were stage 3 and stage 4 larvae located on the liver and in the intestine. 


\section{COPEPODA}

Eudactylina acanthii Scott, 1901

These crustaceans are common parasites of the spiny dogfish examined. The invasion incidence was high $(61.8 \%)$. From 1 to 51 copepods were being found in a fish, the mean population invasion intensity amounting to 4.7 . The parasites occurred on gills. A total of 259 specimens were collected.

\section{Pseudocharopinus bicaudatus(Krфyer, 1837)}

The species was found in the spiracles of one spiny dogfish individual only $(1.8 \%$ invasion incidence), 3 specimens (females with egg sacs) being revealed. The mean population invasion intensity was very low (0.05).

\section{Trifur sp.}

The copepods of the genus were found in stomachs of two spiny dogfish individuals (3.6\% incidence). One of them contained 2 specimens and the other 3 . The parasites usually occur on the outer surfaces of the fish body and in the gill cavity. The parasites had been eaten by the spiny dogfish along with their host. Due to their non-typical location, the crustaceans were damaged, which made it impossible to identify them to species.

\section{DISCUSSION}

The New Zealand spiny dogfish parasitic fauna proved to be relatively poor, as a total of 8 species only, belonging to 5 higher taxa, were revealed. Hewitt and Hine (1972) list 7 species only. A slightly higher number of species was recorded in this host by Orfowska (1979) in the North Sea. She examined a similar number of fish individuals and found 13 species of parasites. The present study as well as that by Orłowska show the parasitic species to differ in their invasion intensities and frequency of occurrence.

The most frequent parasites in the materials examined were the monogeneans Erpocytyle squali. They were found on gills of $96 \%$ of the fish individuals examined. In the North Sea, Orłowska (1979) recorded an incidence lower by a factor of 4; she also reported a lower invasion intensity. The species was recorded in the spiny dogfish off New Zealand by Hewitt and Hine (1972), in the Black Sea by Pogorelceva (1964a), and off Woods Hole, USA by Yamaguti (1963).

Another relatively common parasite is the crustacean Eudactylina acanthii found on gills of $61.8 \%$ of the individuals examined. Orłowska (1979) recorded a similar extent of invasion. The species is widely distributed: it has been recorded in the North Atlantic, Mediterranean Sea, and North Pacific (Markevix, 1956; Kabata, 1979). Raibaut et al. 
(1971) found the parasite in the spiny dogfish off Tunesia. Markevix (1956) and Kabata (1979) described the morphology of the species.

The nematodes Anisakis simplex and Thynnascaris adunca turned out to be rare parasites of the New Zealand spiny dogfish, occurring with incidences of 12,7 and 10.9\%, respectively. Similarly, numbers of parasites in a fish were low in both cases. These data differ : strongly from those for the North Sea where nematodes A.simplex found in $80 \%$ of the spiny dogfish examined (Orłowska, 1979). Off-New Zealand, Anisakis sp. was found in this and other hosts by Hewitt and Hine (1972); Zukov (1960) found them in the Sea of Japan and Okhotsk Sea. The A. simplex larvae are harmful for man. In spite of a weak invasion in the New Zealand spiny dogfish, it seems purposeful to gut the fish and process them thermally, which would kill the nematodes remaining in the body inity. Thadunca were recorded in the spiny dogfish for the first time by Orłowska (1979). Her data indicate an incidence twice that in the present study. These nematodes, occurring as larvae and adults, were recorded in other species of New Zealand by, i.a., Hewitt and Hine (1972), and Grabda and Ślósarczyk (1981).

A still less common parasite of the spiny dogfish examined was the cestode Hepatoxylon megacephalum (7.2\% incidence). The species was described in detail by Dollfus (1942) who listed various chondroid species as hosts, he also mentions the occurrence of plerocercoids in the spiny dogfish off Algier. The larvae and adults occurring in other fish species off New Zealand were recorded by Robinson (1959); that author found plerocercoids of other cestode, Hepatoxylon trichiuri, in spiny dogfish.

The remaining three species: Probolitrema sp., Pseudocharopinus bicaudatus, and Trifur $s p$. were very rare. Their invasion incidences ranged within 1.8-3.6\%. As stated by Yamaguti (1971), the Probolitrema trematodes occur in the body cavity of various chondroid fishes. The specimens found in the stomachs had been probably eaten along with some other fish. P.richiardii was recorded by Yamaguti (1971) in the Atlantic and Mediterranean spiny dogfish. Manter (1954) found P.philippi in this host off New Zealand. Orłowska (1979) recorded a somewhat higher frequency (8.8\% incidence) of Pseudocharopinus bicaudatus in the North Sea. The occurrence of the species in the North Atlantic and Pacific spiny dogfish is mentioned by Markevix (1956) and Kabata (1964, 1979), while Delamare Deboutteville and Nunes (1952) recorded it in the Mediterranean Sea. The Trifur copepods are accidental spiny dogfish parasites. As external parasites of other fish species, their presence in the spiny dogfish stomach resulted from the fact that their proper host had been eaten by the spiny dogfish. A species belonging to the genus Trifur and known from off New Zealand is T.lotellae listed, among others, as a parasite of Macruronus novaezelandiae by Grabda and Slósarczyk (1981).

\section{CONCLUSIONS}

1. The parasitic fauna of the spiny dogfish caught off New Zealand is relatively poor; the materials studied comprised 8 species only, belonging to the Monogenea, Cestoda, Trematoda, Nematoda, and Copepoda. 
2. The parasitic fauna of the host in question shows species and quantitative variabilities depending on the region of occurrence; Orłowska (1979) found 13 species in the North Sea spiny dogfish.

3. The parasites most common in the materials examined were: Erpocotyle squali and Eudactylina acanthii.

4. The survey of the available literature allows to state that the presence of the cestode Hepatoxylon megacephalum, the nematode Thynnascaris adunca, and the crustaceans Eudactylina acanthii and Pseudocharopinus bicaudatus are recorded here for: the first time with respect to the spiny dogfish off New Zealand.

5. Anisakis simplex was the only parasite harmful for man; few individuals were being found $(12.7 \%)$ in the body cavity.

6. The crustacean Trifur $s p$. is an accidental parasite of spiny dogfish, found in the host's stomach.

\section{ACKNOWLEDGEMENTS}

The authors wish to express their gratitude to Dr. Wiesław Slósarczyk of the Sea Fisheries Institute in Gdynia for collecting the materials and making them available.

\section{REFERENCES}

Bigelow H.B., Schroeder W.C., 1948: Fishes of the Western North Atlantic. I, New Haven.

Delamare Deboutteville C., Nunes L.P., 1952: Copépodes parasites des poissons de Banyuls. - Vie et Milieu, 3, 3: 292-300.

Dollfus R.Ph., 1942: Etudes critiques sur les Tétrarhynques du Muséum de Paris. - Arch. Mus. Nation. Hist. Nat., VI Série, 19.

Essafi K., Raibaut A., 1977: Copepodes parasites des poissons de Tunisie. - Bull. Soc. Sc. nat. Tunisie, 12: $23-38$.

Grabda J., Ślósarczyk W., 1981: Parasites of marine fishes from New Zealand. - Acta ichthyol. et piscat., 11, 2: 85-103.

Hewitt G.C., Hine P.M., 1972: Checklist of parasites of New Zealand fishes and of their hosts. - N.Z. Journal of Marine and Freshwater Research, 6, 1-2: 69-114.

Ho J.-S., 1977: Marine Flora and Fauna of the Northeastern United States. Copepoda: Lernaeopodidae and Sphyriidae. - NOAA Technical Report NMFS Circular 406: 1-14.

Kabata Z., 1964: Revision of the genus Charopinus Krфyer, 1863 (Copepoda: Lernaeopodidae). Vidensk. Meddr dansk naturh. Foren., 127: 85-112.

Kabata Z., 1979: Parasitic Copepoda of British Fishes. - The Ray Society, 152, London.

Love M.S., Moser M., 1983: A Checklist of Parasites of California, Oregon, and Washington Marine and Estuarine Fishes. - NOAA Technical Report NMFS SSRF - 777.

Manter H.W., 1954: Some Digenetic Trematodes from Fishes of New Zealand. - Transactions of the Royal Soc. of N.Z., 82, 2:475-568.

Markevič A.P., 1956: Parazitičeskie veslonogie ryb SSSR. - Izd. AN Ukrain. SSR, Kiev. (in Russian) 
Orłowska K., 1979: Parasites of North Sea spiny dogfish, Squalus acanthias L. (Selachiformes, Squalidae). - Acta Ich thyol. et Piscat., 9, 1:33-44.

Pogorelceva T.P., 1964a: Novye i maloizvestnye vidy monogenetičeskih sosalščikov ryb Černogo morja. - Probl. parazit., Trudy Ukrain. respubl. naučn. obšč. Parazit., 3: 30-42. (in Russian)

Pogorelceva T.P., 1964b : Materialy k izučeniju parazitičeskih prostejگ̌ih ryb Černogo morja. - Probl. parazit., Trudy Ukrain. respubl. naučn. ob̌̌č. Parazit., 3: 16-29. (in Russian)

Raibaut A., Hassine O.K.B., Maamouri K., 1971: Copepodes parasites des poissons de Tunisie. - Bull. Inst. Océanogr. Pêche, Salammbô, 2, 2: 169-197.

Robinson E.S., 1959: Records of Cestodes from Marine Fishes of New Zealand. - Transactions of the Royal Soc. of N.Z., 86, 1: 143-153.

Robinson E.S., 1961: Some Monogenetic Trematodes, from marine fishes of the Pacific. Transactions of the American Microscop. Soc., 80, 3: 235-266.

Sulman S.S., 1966: Miksosporidii fauny SSSR. - Izd. Akad. Nauk SSSR, Moskva - Leningrad. (in Russian)

Ślósarczyk W., 1979: Badania łowisk szelfowych Nowej Zelandii. [Investigations of the New Zealand shelf grounds]. - T.G.M., 9: 526-528.

Yamaguti S., 1963: Systema Helminthum. IV. Monogenea and Aspidocotylea. New York - London. Yamaguti S., 1971: Synopsis of Digenetic Trematodes of Vertebrates. I, II. Tokyo, Japan.

Žukov E.V., 1960: Endoparazitičeskie červi ryb Japonskogo morja i Južno-Kyrilskogo melkovodja. Trudy Zool. Inst. Akad. Nauk SSSR, 28: 3-146. (in Russian)

Translated: Dr. Teresa Radziejewska

J. Wierzbicka, D. Łangowska

PARAZYTOFAUNA KOLENIA - SQUALUS ACANTHIAS L.
Z OBSZARU NOWEJ ZELANDII

\section{STRESZCZENIE}

Ryby pochodziły z okolic wysp Snares leżących koło Nowej Zelandii. Zostały odłowione 22 lutego 1978 roku przez statek badawczy R/V „Profesor Bogucki”. Szczegółowej sekcji parazytologicznej poddano 55 koleni. W badanym materiale znaleziono 8 gatunków pasożytów z pięciu grup systematycznych: Monogenea, Cestoda, Trematoda, Nematoda, Copepoda. Najczęściej stwierdzanymi były przywry monogenety czne Erpocotyle squali (96\%) i skorupiaki Eudactylina acanthii $(61,8 \%)$. Pozostałe pasożyty występowały znacznie rzadziej $(1,8-12,7 \%)$. Patogennym dla człowieka był tylko Anisakis simplex znajdowany w jamie ciała w niewielkich ilościach. Po raz pierwszy w tych wodach, stwierdzono u kolenia Hepatoxylon megacephalum, Thynrascaris adunca, Eudactylina acanthii i Pseudocharopinus bicaudatus. Przypadkowym pasożytem okazał się skorupiak Trifur sp. znaleziony w żołądku. $\mathrm{Z}$ badań własnych wynika, że parazy tofauna kolenia $\mathrm{z}$ rejonu Nowej Zelandii jest uboższa w porównaniu z Morzem Północnym, w którym Orłowska (1979) stwierdziła 13 gatunków u tego żywiciela. 
Вежбицка Я., Ланговска Д.

\author{
ППАРАЗИТОФАУНА КАРТАНА - SQUALUS ACANTHIAS L. \\ ИЗ ТЕРРИТОРИИ НОВОЙ ЗЕЛАНДИИ
}

$$
P \text { e } 3 \text { ю }
$$

Материал для исследованин получено из отлова проведённого 22 февраля 1978 г. исследовательским судном "Профессор Богуцки" в близи острова Снарес в окрестностях Новой Зеландии. Подробньм исследованиям подвергалось 55 особей картана.

В исследованном материале установлено присутствие 8 видов паразитов, принадлежащих к 5 систематическим группам: Monogenea, Cestoda, Trematoda. Nematoda, Copepoda. Чִаце всего встречались моногенетические трематоды Erpocotyle squali (96\%) и вакообразные Eudactylina acanthii $(61,8 \%)$. Остальных паразитов присутствовало значительно меньше $(1,8-12,7 \%)$. Патогенньм для человека янлялся исключительно Anisakis simplex, присутствуюдий в полости тела рыбы в небольшом количестве. Виервые установлено у картана из этой территории наличие: Hepatoxylon megacephalum. Thynnascaris adunca, Eudactylina acanthii и Pseudocharopinus bicaudatus. Случайным паразитом являлся ракообразный Trifur sp.. найденный в желудке. На основании полученных результатов установлено, что паразитобауна из территории Новой Зеландии являлась более скудной по сравнению с Северним морем, на территории которого Орловскои (1979) установлено присутствие 13 видов паразитов у этого хозяина.

Authors addresses' Received: 22. December 1983

Dr Jadwiga Wierzbicka

Mgr Danuta Łangowska

Insty tut Ichtiologii A.R.

Kazimierza Królewicza 4

SZCZECIN 71-550

Polska (Poland) 